University of Wollongong

Research Online

Faculty of Business - Papers (Archive)

Faculty of Business and Law

$1-1-2015$

The incidence and perceived managerial merit of customer accounting in

New Zealand

Farzana A. Tanima

Victoria University of Wellington, farzanat@uow.edu.au

Ken Bates

Victoria University of Wellington

Follow this and additional works at: https://ro.uow.edu.au/buspapers

Part of the Business Commons

Research Online is the open access institutional repository for the University of Wollongong. For further information contact the UOW Library: research-pubs@uow.edu.au 


\title{
The incidence and perceived managerial merit of customer accounting in New Zealand
}

\author{
Abstract \\ Purpose - Two prior survey papers on the use and perceived merit of customer accounting (CA) practices, \\ one in Australia and one in New Zealand (NZ), disclosed contrasting results with confusing elements. The \\ purpose of this paper is to replicate and extend previous survey research in order to update and clarify our \\ understanding of CA practices in NZ. \\ Design/methodology/approach - Within a contingency theory framework, a mail questionnaire survey is \\ used to measure the use and perceived merit of CA practices in NZ and investigate their relationship with \\ six contingent factors: competitive strategy, market orientation, environmental uncertainty, costing \\ methodology, company size and industrial sector. \\ Findings - Mean CA usage and perceived merit scores in NZ in 2009 are much higher than was found in \\ $\mathrm{NZ}$ in 2007 and similar to those found in Australia in 2002. A significant gulf between usage rates of \\ historical and forward-looking CA measures is now found in NZ. There is strong evidence for a positive \\ contingent relationship between the marketing concept of marketing management and both the use and \\ perceived merit of historical CA measures. Also found is a significant positive relationship between the \\ customer concept of marketing management and the use and perceived merit of customer profitability \\ analysis at the individual customer level. \\ Research limitations/implications - The survey method used prevents follow-up questions and \\ clarification of ambiguities, but the survey results do provide new insights and potential avenues for \\ further research. \\ Originality/value - This survey provides researchers, teachers and firms using or considering using CA \\ practices, with an improved understanding of current usage and perceived merit of CA practices in NZ \\ companies. \\ Disciplines \\ Business \\ Publication Details \\ Tanima, F. Aman. \& Bates, K. (2015). The incidence and perceived managerial merit of customer \\ accounting in New Zealand. Pacific Accounting Review, 27 (4), 466-485.
}

This journal article is available at Research Online: https://ro.uow.edu.au/buspapers/1091 


\title{
The incidence and perceived managerial merit of
}

\author{
customer accounting in New Zealand
}

\begin{abstract}
Purpose - Two prior survey papers on the use and perceived merit of customer accounting (CA) practices, one in Australia and one in New Zealand (NZ), disclosed contrasting results with confusing elements. This survey replicates and extends the previous research to update and clarify our understanding of CA practices in NZ.

Design/methodology/approach - Within a contingency theory framework, a mail questionnaire survey is used to measure the use and perceived merit of CA practices in NZ and investigate their relationship with six contingent factors: competitive strategy; market orientation; environmental uncertainty; costing methodology; company size and industrial sector.

Findings - Mean CA usage and perceived merit scores in NZ in 2009 are much higher than was found in NZ in 2007 and similar to those found in Australia in 2002. A significant gulf between usage rates of historical and forward-looking CA measures is now found in NZ. There is strong evidence of a positive contingent relationship between the marketing concept of marketing management and both the use and perceived merit of historical CA measures. Also found is a significant positive relationship between the customer concept of marketing management and the use and perceived merit of customer profitability analysis at the individual customer level.
\end{abstract}

Research limitations/implications - The survey method used prevents follow-up questions and clarification of ambiguities, but the survey results do provide new insights and potential avenues for further research.

Originality/value - This survey provides researchers, teachers and firms using, or considering using CA practices with an improved understanding of current usage and perceived merit of CA practices in NZ companies.

Keywords - Customer accounting; Customer profitability analysis; Customer lifetime value; Customer equity; Customer concept; New Zealand.

Paper type - Research paper.

The authors thank the Editors of Pacific Accounting Review and two anonymous referees for suggestions that considerably improved this paper, and we thank Atiyab Habib and Dalice Sim for assistance with the statistical analysis. 


\section{Introduction}

Despite many firms adopting a strategy based on customer intimacy (Treacy and Wiersema, 1993) the accounting literature on CA is described as "little more than fledgling" (McManus and Guilding, 2008, p. 783), particularly when compared to the broader marketing literature on customer-focused metrics. Gleaves et al. (2008, p. 825) suggest that marketing requires support from management accounting (MA) to "shore-up and clarify" its CA measures. Bates and Whittington (2009) find such support lacking, as they observe minimal coverage of customer profitability analysis (CPA) in MA textbooks and nothing on the forward-looking measures of customer lifetime value (CLV) and customer equity (CE). If "management accounting must serve the strategic objectives of the firm" (Kaplan, 1984, p. 414), there is a danger that MA is failing firms with a customer-focused strategy, particularly if the "dearth of empirical research concerned with customer accounting" (Guilding and McManus, 2002, p. 45) reflects limited usage of $\mathrm{CA}$ in practice. This research study investigates whether or not such a potential information gap exists, by updating and extending our understanding of the use and perceived merit of CA practices in NZ.

The only two prior surveys investigating usage and perceived merit of CA practices disclose contrasting results. Guilding and McManus (2002) survey large Australian companies and find higher usage rates "than one might have reasonably anticipated" (p. 56) considering the limited accounting literature on CA. They discover that forward-looking measures, CLV[1] and CE[2], are the least used. They find a significant positive association between market orientation and CA usage, but only a weak association between competitive intensity and CA usage. In contrast, Lord et al. (2007)[3] find lower CA usage and perceived merit rates in NZ and no significant association between either market orientation or competitive intensity and CA usage. These contrasting results within the limited accounting literature on $\mathrm{CA}$ provide the main justification for this replication and extension of prior surveys.

Both prior CA surveys only investigated the effect on CA of two contingent variables: market orientation and competitive intensity. Lord et al. (2007, p. 56) suggest that competitive strategy (CS), industry type and company size are other factors worthy of investigation. The literature review below confirms that these additional variables are likely to have an association with CA usage and perceived merit and they are therefore included in this study. In general surveys of costing practices, the need for CPA is often cited as a reason for the adoption of activity-based costing (ABC) (Innes and Mitchell, 1995; Innes et al., 2000; Cotton et al., 2003). Kaplan and Narayanan (2001) suggest using ABC methodology for monitoring "the longitudinal variation of customers over time to calculate their total life-cycle profitability" (p. 13), a rare mention of the need for a forward-looking CA metric (like CLV) to be found in the accounting literature. Given the literature advice that $\mathrm{ABC}$ based $\mathrm{CA}$ practices are needed, this study tests for a relationship between $\mathrm{ABC}$ adoption and the usage and perceived merit of $\mathrm{CA}$.

The remainder of this paper is organized as follows. Firstly an analysis of the literature on CA highlights the limited coverage, identifies gaps, and emphasises the contrasting results of the two prior surveys of CA practices in Australia and NZ. Subsequent sections present the theoretical perspective that underpins this research, its objectives and research method, the survey findings and a comparison of results with those of the two prior surveys. Finally, conclusions and 
suggested areas for future research are discussed. Table 8 (Appendix) lists all acronyms used in this paper.

\section{The literature on customer accounting}

Kotler (2003) identifies a shift in marketing strategy from a product to a customer focus and yet claims that many companies measure customer satisfaction, but most fail to measure customer profitability (CP). Kaplan and Cooper (1998, p.184) highlight how in the Kanthal case (Kaplan, 1989 ) the top $20 \%$ of customers generate $225 \%$ of profits, whilst the bottom $10 \%$ of customers lose $125 \%$ of profits. Similarly, Shank's (1996) Allied Stationery Products case[4] demonstrates how ABC identifies customer specific costs and finds that the top 5\% of customers contribute $80 \%$ and the next $45 \%$ of customers contribute $220 \%$ of profits, however, the next $48 \%$ of customers lose $140 \%$ whilst the bottom $2 \%$ of customers lose the final $60 \%$ of profits. Kaplan and Cooper (1998) stress that manufacturing costs, and operating costs in service industries, can be strongly influenced by customer demands, and claim that this "causes customer costing to become even more important than product costing" (p. 189). A further motivation for this study is therefore to investigate whether customer costing has in fact become more important than product costing, by surveying the usage and perceived merit of CA practices.

Foster et al., (1996) observe that most MA systems rarely measure CP. Shields (1997) conducts a seven-year content survey on major accounting journals but finds no CA articles. Smith (2002) surveys 15 years of accounting literature and finds less than one major CPA paper per year. Bjørnenak and Mitchell (2002) analyse the "voluminous" (p. 503) activity-based costing/cost management $(\mathrm{ABC} / \mathrm{M})$ journal output to provide insights into $\mathrm{ABC} / \mathrm{M}$ 's rapid rise in prominence from an initial focus on "product profitability assessment" (p. 504) through the development of $\mathrm{ABC} / \mathrm{M}$ to "the complementarities of $\mathrm{ABC} / \mathrm{M}$ to other new high-profile management and accounting techniques" (p. 504). However, no specific mention is made of any CA measures.

This brief review of accounting literature on CA demonstrates high levels of interest in $\mathrm{ABC} / \mathrm{M}$ (Bjørnenak and Mitchell, 2002), but a minimal coverage of CA which is mainly focused on historical CPA, whilst largely ignoring the forward-looking measures like CLV and CE (Bates and Whittington, 2009; Gleaves et al., 2008) that are most prevalent in the marketing literature (see below). This explains why Guilding and McManus (2002) describe the accounting literature on CA as fledgling and were surprised to find relatively high usage rates for historical CPA measures in Australia. They report mean usage rates of both historical CA measures, customer profitability analysis-individual customer (CPAIC)[5] and customer segment profitability analysis (CSPA), above the midpoint on their 7 point Likert measurement scale[6]. However, they find statistically significantly lower usage rates for the forward-looking CA measures, CLV and $\mathrm{CE}$, and consider this further evidence of accounting short-termism as 'a conspicuous aspect of the findings" (p. 56). They also find that perceived merit scores for all CA practices were significantly higher than usage rates, thus indicating scope for increased CA usage in the future.

Lord et al. (2007) disclose significantly lower rates for usage and perceived merit of CA in NZ than was found in the Australian study, except for CE (which had the same mean usage rate in both studies). NZ usage rates for all CA practices are below the scale's midpoint and the practices are ranked in a different order in the NZ study. The conflicting results of prior studies and the desire to establish whether CA usage rates rise over time, add further motivations for this replication study. 
The marketing literature on CA "is much more broad-ranging with much greater attention directed to the less measurable facets of customer related performance, lifetime customer valuation analysis" (McManus and Guilding, 2008, p. 785) and the use of historical CPA is described as common (Blattberg and Deighton, 1991; Storbacka, 1997; Mulhern, 1999; Jacobs et $a l ., 2001)$. But, in contrast to the accounting literature, the marketing literature focuses on future oriented metrics like CLV and CE. The literature on CE demonstrates that marketing treats the customer as an asset (Bell et al., 2002; Storbacka, 2006). Blattberg and Deighton (1996) suggest that the CE metric is a key criterion in finding a balance between customer acquisition and retention. However, both prior surveys find statistically significantly lower usage rates for the forward-looking CA measures, CLV and CE, than for the historical CA measures. This apparent discrepancy between actual practice and the more prolific marketing literature further justifies this replication study.

Kotler (2003, p. 18) explains that the production, product and selling concepts of marketing management are all based on "a product centred "make-and-sell" philosophy" and that when the marketing concept emerged in the 1950s there was a shift to "a customer-centred, "sense-andrespond" philosophy". He explains that the marketing concept "focuses on customer needs... and produces profits by satisfying customers" (p. 20) and cites Narver and Slater's (1990) empirical evidence that firms adopting this concept achieve superior performance. Such firms focus on customer segments and should benefit from measuring CSPA. Moreover, Kotler (2003) advises firms that adopt the customer concept, and hence forge one to one relationships with their customers, to measure CPAIC. This study investigates to what extent his advice has been heeded and uses the marketing and customer concepts as proxies for market orientation.

It is intuitive that large companies with a large customer base may benefit from the use of CA practices, and Al-Omiri and Drury (2007) find company size to be significantly related to the level of sophistication of a company's costing system. This study therefore investigates whether company size is associated with the use and perceived merit of CA practices. In line with Guilding and McManus (2002) and Lord et al. (2007) turnover is used to measure company size.

Foster and Gupta (1994) argue that it is difficult to calculate customer revenues and costs, and as these are contingent on the products and services sold by a firm it follows that the type of profitability measures used may vary between industry sectors. Moreover, there is evidence within the literature that the financial services sector is utilising CPA (Hart and Smith, 1998; Rafiq and Garg, 2002; Mitchell, 2004) and would benefit from using CLV (Kaplan and Narayanan, 2001). Thus, this study investigates whether CA practices are most heavily used and/or perceived to be most beneficial in the financial services sector.

Lord et al. (2007) cited Lindsay $(1994,1995)$ as support for the importance of replication to establish the validity and significance of prior research findings, and to establish whether the results also hold under different conditions. They therefore conducted a faithful NZ replication of the Guilding and McManus (2002) Australian survey on the use and perceived merit of CA practices and found contradictory results in several respects, including significantly lower usage and perceived merit scores in NZ compared to Australia. Moreover, they suggest an opportunity to improve the research method by not using an all-inclusive category called CA, as this 
appeared to cause confusion and thus distorted results[7]. This advice is followed in the current survey. 


\section{Theoretical perspective}

MA should not develop its own set of procedures and measurement systems and universally apply these to all firms "without regard to the underlying values, goals and strategies of particular firms" (Kaplan (1984, p.414). Otley (1980) concurs that there is no universally applicable accounting system and describes how a contingency theory must "identify specific aspects of an accounting system which are associated with certain defined circumstances and demonstrate an appropriate matching" (p. 413, author's emphasis). It is therefore appropriate that Guilding and McManus (2002, p. 48) used "a contingency theory of customer accounting" to develop hypotheses to test in their survey of CA usage and perceived merit in Australia. In management control systems (MCS) research a contingency theory framework is used to establish "how MCS are best designed and implemented to 'fit' the context, or contingencies, within which MCS are employed" (Chenhall and Chapman, 2006, p. 35). Otley (1980, p. 414) describes two main uses of contingency theory in MA research, firstly to theorise the contingent factors that influence MCS design and secondly to interpret contingent results that have emerged from a particular study or from a comparison of two or more prior studies. Both these approaches are used here, firstly, contingency theory is used, in combination with an analysis of relevant literature, to identify the contingent factors that may influence the usage and perceived merit of CA practices and to develop suitable hypotheses to be tested. Secondly, contingency theory is used, again in conjunction with the literature, to help explain the survey results and any similarities and inconsistencies between this survey and the two prior surveys.

In the next section, this study's research objectives are explained and, on the basis of the literature analysis above, decomposed into research questions and testable hypotheses.

\section{Research objectives}

The aim of this research is to update and extend our knowledge on the usage and perceived merit of CA. This is achieved by replicating and extending the Lord et al. (2007) study, which was a replication of Guilding and McManus (2002). Consequently the research objectives are the same as for both prior studies:

1. to appraise the incidence of customer accounting;

2. to assess the practitioners' perceptions of CA's merit as a managerial tool; and

3. to develop and test hypotheses concerned with contingent factors that might affect the use and perceived merit of CA.

However, compared to the two prior surveys, this study tests additional contingent factors and adjusts the methodology used to avoid the problems evident in the prior New Zealand survey, identified above, which may have also affected the Australian survey. Research objectives 1 and 2 are addressed by asking the same questions as used in the prior surveys (see section 5.2.1 and 5.2.2). Research objective 3 is addressed by posing appropriate research questions relating to the contingent factors identified in the literature review and formulating hypotheses to be tested through the questionnaire survey. These research questions, hypotheses and the constructs for the independent variables being tested are summarised in Table 1 . 
Table 1: Summary of the formulated hypotheses

\begin{tabular}{|c|c|c|c|}
\hline Research Questions & $\begin{array}{l}\text { Hypotheses for CA } \\
\text { usage }\end{array}$ & $\begin{array}{l}\text { Hypotheses for perceived } \\
\text { managerial merit of CA }\end{array}$ & $\begin{array}{l}\text { Independent variables } \\
\text { (see explanations in section } 5, \text { p.7-9) }\end{array}$ \\
\hline $\begin{array}{l}\text { To what extent is the use or } \\
\text { perceived merit of any CA } \\
\text { measure contingent on the } \\
\text { employment of a differentiated } \\
\text { CS? }\end{array}$ & $\begin{array}{l}\text { Hla: CA usage rates } \\
\text { are higher in companies } \\
\text { with a highly } \\
\text { differentiated CS. }\end{array}$ & $\begin{array}{l}H 1 b: \text { the perceived } \\
\text { managerial benefit of CA is } \\
\text { greater in companies with a } \\
\text { highly differentiated CS. }\end{array}$ & $\begin{array}{l}\text { CS-cost leadership. } \\
\text { CS-differentiation. } \\
\text { CS-focus cost leadership. } \\
\text { CS-focus differentiation. } \\
\text { CS-defender. } \\
\text { CS-prospector. } \\
\text { CS-analyser. }\end{array}$ \\
\hline $\begin{array}{l}\text { To what extent is the use or } \\
\text { perceived merit of any CA } \\
\text { measure contingent on the } \\
\text { employment of either the } \\
\text { marketing or customer concept } \\
\text { of marketing management? }\end{array}$ & $\begin{array}{l}\text { H2a: CA usage is } \\
\text { higher in companies } \\
\text { that adopt the marketing } \\
\text { or customer concept of } \\
\text { marketing management. }\end{array}$ & $\begin{array}{l}H 2 b: \text { the perceived } \\
\text { managerial merit of CA is } \\
\text { greater in companies that } \\
\text { adopt the marketing or } \\
\text { customer concept of } \\
\text { marketing management. }\end{array}$ & $\begin{array}{l}\text { Production concept } \\
\text { Product concept } \\
\text { Selling concept } \\
\text { Marketing concept } \\
\text { Customer concept }\end{array}$ \\
\hline $\begin{array}{l}\text { To what extent is the use or } \\
\text { perceived merit of any CA } \\
\text { measure contingent on the level } \\
\text { of stability in the environment } \\
\text { in which the firm operates? }\end{array}$ & $\begin{array}{l}\text { H3a: CA usage rates } \\
\text { are higher in companies } \\
\text { which operate in an } \\
\text { unstable environment } \\
\text { than in companies } \\
\text { which operate in a } \\
\text { stable environment. }\end{array}$ & $\begin{array}{l}H 3 b: \text { the perceived } \\
\text { managerial benefit of CA is } \\
\text { greater in companies which } \\
\text { operate in an unstable } \\
\text { environment than in } \\
\text { companies which operate in } \\
\text { a stable environment. }\end{array}$ & $\begin{array}{l}\text { Environmental uncertainty is } \\
\text { conceptualised by reference to } \\
\text { organisational structure. The more stable } \\
\text { and certain the environment, the more } \\
\text { mechanistic the structure. The more } \\
\text { unstable and uncertain the environment, } \\
\text { the more organic the structure. }\end{array}$ \\
\hline $\begin{array}{l}\text { To what extent is the use or } \\
\text { perceived merit of any CA } \\
\text { measure contingent on the use } \\
\text { of an ABC system? }\end{array}$ & $\begin{array}{l}\mathrm{H} 4 \mathrm{a}: \text { CA usage rates } \\
\text { are higher in companies } \\
\text { using ABC systems. }\end{array}$ & $\begin{array}{l}H 4 b: \text { the perceived } \\
\text { managerial benefit of CA is } \\
\text { greater in companies using } \\
\text { ABC systems. }\end{array}$ & $\begin{array}{l}\text { Costing methodology is conceptualised } \\
\text { by reference to the need for an } A B C \\
\text { system. }\end{array}$ \\
\hline $\begin{array}{l}\text { To what extent is the use or } \\
\text { perceived merit of any CA } \\
\text { measure contingent on the size } \\
\text { of the firm? }\end{array}$ & $\begin{array}{l}\text { H5a: CA usage rates } \\
\text { are higher for larger } \\
\text { companies. }\end{array}$ & $\begin{array}{l}H 5 b: \text { the perceived } \\
\text { managerial benefit of CA is } \\
\text { greater in larger companies. }\end{array}$ & Company size is measured by turnover. \\
\hline $\begin{array}{l}\text { To what extent is the use or } \\
\text { perceived merit of any CA } \\
\text { measure contingent on industry } \\
\text { sector? }\end{array}$ & $\begin{array}{l}\text { H6a: CA usage rates } \\
\text { are higher in companies } \\
\text { within the financial } \\
\text { service industry than in } \\
\text { other industries. }\end{array}$ & $\begin{array}{l}\text { H6b: the perceived } \\
\text { managerial merit of CA is } \\
\text { greater in companies within } \\
\text { the financial services } \\
\text { industry than in other } \\
\text { industries. }\end{array}$ & $\begin{array}{l}\text { Industrial sector is conceptualised by } \\
\text { reference to whether the company is in } \\
\text { the financial services sector or not. }\end{array}$ \\
\hline
\end{tabular}

\section{Method and variable measurement}

This section describes the survey method applied and explains how the survey questions were used to obtain appropriate measurement of contingent variables. Yin (2009) advises that survey methods help the researcher to describe the incidence and prevalence of a phenomenon, in this case the usage and perceived merit of CA practices. This study uses contingency theory to identify contingent variables that may influence the usage and perceived merit of CA practices and to develop appropriate hypotheses (Table 1) which are tested on the survey data.

\subsection{Sampling procedures}

The initial intention was to mail a questionnaire survey to chief accountants and marketing managers of all 145 companies, with New Zealand addresses, listed on the New Zealand Stock Exchange (NZX). To improve the response rate, research was conducted to identify recipients by name, and thus 9 companies were excluded[8]. These exclusions are not expected to bias the sample. 17 responses were received within two weeks and a further 35 responses were received 
following phone calls. 8 questionnaires were not completed[9] and hence from the 136 companies surveyed there are 44 usable responses, with 37 responses from chief accountants and 7 from marketing managers, all from different companies. Given the time constraints[10], it was decided to continue analysis of data with a total response rate of $32.4 \%$ as this is considered acceptable and is comparable to the previous two studies. Table 2 summarises comparative statistics for this survey and the two prior surveys.

Table 2: Comparison of survey statistics

\begin{tabular}{|l|c|c|c|}
\hline & $\begin{array}{c}\text { Number } \\
\text { Mailed }\end{array}$ & $\begin{array}{c}\text { Usable } \\
\text { Responses }\end{array}$ & $\begin{array}{c}\text { Response } \\
\text { rate }\end{array}$ \\
\hline This Survey & 136 & 44 & $32.4 \%$ \\
Lord et al. (2007) & 143 & 58 & $40.6 \%$ \\
Guilding and McManus (2002) & 251 & 124 & $49.4 \%$ \\
\hline
\end{tabular}

\subsection{Variable measurement}

The CA practices surveyed, and their acronyms, are listed in Table 3. These CA practices and all independent variables are defined in the "Glossary of Terms used in the Questionnaire" (Appendix) which was sent to all participants. The survey instrument is available from the authors on request. The analysis of data collected is explained below.

Table 3: Dependent variables: usage and perceived merit of CA practices

\begin{tabular}{|l|l|}
\hline CA Practices & Acronyms \\
\hline Customer profitability analysis-individual customers & CPAIC \\
\hline Customer segment profitability analysis & CSPA \\
\hline Customer lifetime value & CLV \\
\hline Customer equity & CE \\
\hline
\end{tabular}

\subsubsection{CA usage}

As in both prior surveys, participants were asked: To what extent does your company use the following practices? A Likert scale ranging from 1 (not at all) to 7 (to a large extent) was provided next to each of the four CA practices (Table 3) or N/A[11] could be circled if a practice was not applicable to the company.

\subsubsection{Perceived managerial merit of $C A$}

As in both prior surveys, participants were asked: To what extent do you consider the following practices are or would be a useful aid to management in your company? The same four CA practices and 7 point scale with N/A option was provided.

\subsubsection{Competitive strategy.}

Participants were asked: To what extent do you consider these types of competitive strategy are utilized by your company? The seven competitive strategies in Table 2 were listed. The same scale, with N/A option, was provided. 


\subsubsection{Market orientation.}

Market orientation was represented by concepts of marketing management (Kotler, 2003) in the questionnaire. The following question was asked: To what extent do you consider these types of market orientation are adopted by your company? The five marketing management concepts in Table 2 were listed. The same scale, with N/A option, was provided.

\subsubsection{Environmental uncertainty.}

Environmental uncertainty was represented as organisational structure in the questionnaire. The following question was asked: Where do you consider your organisation lies on the continuum between 1 = 'totally mechanistic' to 7 = 'totally organic'? A 7 point Likert scale enabled respondents to indicate the company's position between two extremes: 'totally mechanistic' and 'totally organic'.

\subsubsection{Costing methodology.}

The following question was asked: Does your organisation use ABC methodology for the determination of profitability cut by product, customer or otherwise? Participants could answer either yes or no. The independent variable $\mathrm{ABC}$ is dichotomous, taking a value of 1 if $\mathrm{ABC}$ is used and 0 if not.

\subsubsection{Company size.}

Turnover (measured in \$NZ millions) represents company size. The participants selected one of four options: below 5, between 5 and 15, between 15 and 50, above 50. The independent variable, company size is dichotomous ( 1 for companies with turnover above \$NZ 15 million, 0 for companies with turnover below \$NZ 15 million).

\subsubsection{Industrial sector.}

For industrial sector, the participants could select from a list of 17 different industrial sectors or specify their company's sector in writing. The independent variable for industrial sector is dichotomous ( 1 for finance companies, 0 for any other companies).

\section{Results}

6.1 Descriptive statistics

For ease of comparison, the descriptive statistics of CA usage rates from this study and the two prior studies are reproduced in Table 4. Mean usage rates of historical CA measures, CSPA and CPAIC, are both above the midpoint on the Likert scale, but mean usage rates of forwardlooking measures, CLV and CE, are both below the midpoint. 
Table 4: Descriptive statistics for CA usage rates for this study and prior studies

\begin{tabular}{|l|c|c|c|c|c|c|}
\hline & \multicolumn{2}{|c|}{ This study } & \multicolumn{2}{c|}{$\begin{array}{c}\text { Guilding and } \\
\text { McManus } \\
(2002, \text { p. 52) }\end{array}$} & \multicolumn{2}{c|}{$\begin{array}{c}\text { Lord } \text { et al. } \\
\text { (2007, p. 51) }\end{array}$} \\
\hline CA practices & Mean & SD & Mean & SD & Mean & SD \\
\hline Customer accounting (CA) & n/a & n/a & 4.22 & 2.14 & 3.08 & 1.73 \\
\hline $\begin{array}{l}\text { Customer segment profitability } \\
\text { analysis (CSPA) }\end{array}$ & 4.55 & 1.92 & 4.12 & 2.14 & 3.70 & 2.11 \\
\hline $\begin{array}{l}\text { Customer profitability analysis- } \\
\text { individual customer (CPAIC)[5] }\end{array}$ & 4.30 & 2.10 & 4.03 & 2.10 & 3.98 & 2.04 \\
\hline Customer lifetime value (CLV)[1] & 2.65 & 1.96 & 2.64 & 1.89 & 2.37 & 1.50 \\
\hline Customer equity (CE)[2] & 2.05 & 1.65 & 2.58 & 1.96 & 2.58 & 1.73 \\
\hline
\end{tabular}

$$
\mathrm{SD}=\text { Standard deviation. } \quad \mathrm{n} / \mathrm{a}=\text { not applicable }
$$

Except for CE, this survey, conducted in October 2009, finds higher usage of all CA practices than did the prior NZ survey. Moreover, the results of this study are much more comparable to the 2002 Australian study, as CA practice mean usage rates are similar and in the same rank order. Hence, a similar gulf between the mean usage rates of the historical and forward-looking CA measures is evident in this survey and the prior Australian survey. This contrasts with the prior NZ findings that CPAIC has the highest mean score and CLV has the lowest. T-tests disclose that usage rates of CLV, CE and CA are all significantly higher in the Australian study than in the prior NZ study ( $\mathrm{t}=6.61,5.42$ and 3.69 respectively, all $\mathrm{p}<0.001)$. However, no significant differences are observed between mean usage rates in this study and the prior Australian study. The usage of CSPA was found to be significantly higher in this study than in the prior NZ study, $(t=2.917, \mathrm{p}<0.01)$. It is possible that CA usage rates in NZ increased over the two intervening years, but some part of the observed difference could be caused by the exclusion from this study of the holistic term CA[7], which appeared to cause confusion in the prior NZ study. Hence, the higher usage scores reported in the present study, in comparison to the prior New Zealand study, may indicate that exclusion of the holistic term CA from the list of practices has improved survey accuracy.

Finally, a Wilcoxon related samples test is used to determine if the mean usage scores of the four CA practices were significantly different from each other and reveals that both CSPA and CPAIC are used significantly more than CLV and CE $(\mathrm{p}<0.001)$. This confirms that the gulf observed between the mean usage rates of the historical CA practices and the forward-looking CA practices is in fact a statistically significant difference, just as it was in the prior Australian study.

The descriptive statistics of CA perceived merit scores disclosed by this study and the two prior studies are reproduced in Table 5. This study finds that the mean managerial merit scores for CA practices range from 5.59 for CSPA to 3.48 for CE and that their rank order is the same as for usage. The mean merit scores are all above the midpoint of the measurement scale, except for CE. Wilcoxon related sample tests determine that mean merit scores for all four CA practices are significantly higher $(\mathrm{p}<0.001)$ than mean usage scores and that the perceived merit of CPAIC was significantly higher than that of CLV $(p<0.005)$ and CE $(p<0.001)$, the perceived merit of 
CSPA was significantly higher than that of CLV $(\mathrm{p}<0.001)$ and CE, $(\mathrm{p}<0.001)$ and the perceived merit of CLV was significantly higher than that of CE $(p<0.005)$.

Table 5: Descriptive statistics for perceived managerial merit of CA for this study and prior studies

\begin{tabular}{|l|c|c|c|c|c|c|}
\hline & \multicolumn{2}{|c|}{ This study } & \multicolumn{2}{c|}{$\begin{array}{c}\text { Guilding and } \\
\text { McManus } \\
(\mathbf{2 0 0 2} \text { p. 52) }\end{array}$} & \multicolumn{2}{c|}{$\begin{array}{c}\text { Lord } \text { et al. } \\
(2007, \text { p. 51) }\end{array}$} \\
\hline CA practices & Mean & SD & Mean & SD & Mean & SD \\
\hline Customer accounting (CA) & n/a & n/a & 5.21 & 1.93 & 3.82 & 1.95 \\
\hline $\begin{array}{l}\text { Customer segment profitability } \\
\text { analysis (CSPA) }\end{array}$ & 5.59 & 1.56 & 5.28 & 1.87 & 4.35 & 2.13 \\
\hline $\begin{array}{l}\text { Customer profitability analysis- } \\
\text { individual customer (CPAIC)[5] }\end{array}$ & 5.36 & 1.87 & 5.08 & 2.04 & 4.86 & 2.11 \\
\hline Customer lifetime value (CLV)[1] & 4.30 & 2.08 & 4.38 & 2.08 & 3.56 & 1.93 \\
\hline Customer equity (CE)[2] & 3.48 & 2.14 & 4.19 & 2.07 & 3.57 & 1.95 \\
\hline
\end{tabular}

$$
\mathrm{SD}=\text { Standard deviation. } \quad \mathrm{n} / \mathrm{a}=\text { not applicable }
$$

T-tests reveal that the mean perceived merit scores of four out of five CA practices in the Australian study are statistically significantly higher than those of the prior NZ study, and that only CPAIC is not significantly higher. However, there are no significant differences between the perceived merit scores reported in this study and those disclosed in the Australian study. This suggests that NZ businesses have become more aware of the merits of using CA than was disclosed previously. Excepting for CE, the perceived merit scores of the CA practices in this study are all greater than those reported in the prior NZ study. Comparison of means using t-tests suggests that the perceived merit of CLV in this study was significantly higher than was reported in the prior NZ study $(\mathrm{t}=3.037, \mathrm{p}<0.005)$. This suggests that $\mathrm{NZ}$ managers now value the forward-looking CA practice CLV more highly than was reported previously.

\subsection{Regression analysis}

Calculation of Pearson product moment correlation coefficients highlighted a multicollinearity problem if all our independent variables were included individually in the regression analysis. As some of the CS and marketing concept variables were highly correlated, principle component factor analysis was conducted to identify any appropriate combinations of either CS or marketing concept variables. The factor analysis identified two clusters of related CS variables as follows: cost leadership, focus cost leadership and defender strategies combined to form the construct $C S$ cost leadership/defender. The variables differentiation, focus differentiation and prospector strategies combined to form the construct CS: differentiation/prospector. Such combinations of strategy typologies are intuitive and consistent with prior contingency theory literature (Langfield-Smith, 1997). Factor analysis did not suggest any appropriate combinations for the marketing concept variables. It was thought appropriate to eliminate the production, product and selling concepts and retain the marketing and customer concepts as the factors most relevant to $H 2 a$ and $H 2 b$ (Table 1). Subsequent calculation of Pearson product moment correlation coefficients between the remaining variables indicates that multicollinearity is no longer a problem for the regression analysis undertaken. All correlation coefficients between remaining 
independent variables are below 0.4 and VIF values are well below the accepted threshold of 10 and tolerance values above the accepted threshold of 0.2 (Tables 6 and 7).

The results of the regression analysis, where the CA practice usage rates are the dependent variables, are presented in Table 6. Two of the four regression equations are statistically significant ( $\mathrm{p}<0.10$ and less) with adjusted $\mathrm{R}^{2} \mathrm{~s}$ of 0.411 for CSPA and 0.371 for CPAIC. No significant relationships are identified for CLV and CE.

Table 6: CA usage rates regression analysis

\begin{tabular}{|l|c|c|c|c|}
\hline & $\begin{array}{l}\text { Customer profitability } \\
\text { analysis-individual } \\
\text { customers } \\
\text { (CPAIC) }\end{array}$ & $\begin{array}{l}\text { Customer segment } \\
\text { profitability analysis } \\
\text { (CSPA) }\end{array}$ & $\begin{array}{l}\text { Customer lifetime } \\
\text { value (CLV) }\end{array}$ & $\begin{array}{l}\text { Customer equity } \\
\text { (CE) }\end{array}$ \\
\hline Constant & $0.824(0.629)$ & $0.265(0.201)$ & $0.576(0.340)$ & $0.422(0.308)$ \\
\hline CS-analyser & $0.372(2.412)^{* * *}$ & $0.35(2.263)^{* * *}$ & $0.172(0.870)$ & $-0.169(-1.047)$ \\
\hline CS-differentiation/prospector & $0.527(1.136)$ & $-0.581(-1.247)$ & $0.174(0.295)$ & $0.735(1.516)^{*}$ \\
\hline CS-cost leadership/defender & $-0.360(-1.292)$ & $-0.025(-0.091)$ & $-0.171(-0.480)$ & $0.154(0.529)$ \\
\hline Marketing concept & $0.325(1.939)^{* *}$ & $0.472(2.807)^{* * *}$ & $0.214(0.996)$ & $-0.006(-0.033)$ \\
\hline Customer concept & $0.265(1.361)^{*}$ & $0.090(0.461)$ & $0.163(0.652)$ & $0.105(0.515)$ \\
\hline Environmental uncertainty & $0.139(0.698)$ & $-0.152(-0.760)$ & $0.124(0.486)$ & $0.413(1.986)^{* *}$ \\
\hline Costing methodology & $0.836(1.342)^{*}$ & $0.733(1.171)$ & $0.006(0.007)$ & $1.004(1.540)$ \\
\hline Company size & $0.046(0.218)$ & $0.326(1.551)^{*}$ & $0.170(0.631)$ & $-0.048(-0.218)$ \\
\hline Industrial sector & $1.236(1.779)^{* *}$ & $0.038(0.054)$ & $-0.823(-0.926)$ & $0.562(0.773)$ \\
\hline Adjusted R2 & 0.411 & 0.371 & 0.049 & 0.019 \\
\hline F & 4.028 & 3.560 & 0.805 & 1.086 \\
\hline P & $0.002 * * *$ & $0.004 * * *$ & 0.615 & 0.401 \\
\hline VIF & 1.2712 & 1.2712 & 1.2736 & 1.2712 \\
\hline Tolerance & 0.8004 & 0.8004 & 0.7965 & 0.8004 \\
\hline
\end{tabular}

$\mathrm{CS}=$ competitive strategy. Each cell in the table above presents the regression coefficients, followed by the t-value in brackets. All t-tests are one-tailed tests of significance: $* \mathrm{p}<0.10 \quad * * \mathrm{p}<0.05 \quad * * * \mathrm{p}<0.01$

The results of the regression analysis, where the CA practice perceived merit rates are the dependent variables, are presented in Table 7. Two of the four regression equations are statistically significant $\left(\mathrm{p}<0.01\right.$ ), with adjusted $\mathrm{R}^{2} \mathrm{~s}$ of 0.56 for CPAIC and 0.45 for CSPA. No significant relationships are identified for CLV and CE. 
Table 7: CA perceived merit regression analysis

\begin{tabular}{|c|c|c|c|c|}
\hline & $\begin{array}{l}\text { Customer profitability } \\
\text { analysis-individual } \\
\text { customers } \\
\text { (CPAIC) }\end{array}$ & $\begin{array}{l}\text { Customer segment } \\
\text { profitability analysis } \\
\text { (CSPA) }\end{array}$ & $\begin{array}{l}\text { Customer lifetime } \\
\text { value }(\mathrm{CLV})\end{array}$ & $\begin{array}{l}\text { Customer equity } \\
\text { (CE) }\end{array}$ \\
\hline Constant & $0.986(0.930)$ & $2.103(2.120)$ & $0.143(0.089)$ & $0.713(0.396)$ \\
\hline CS-analyser & $0.358(2.867)^{* * *}$ & $0.236(2.017)^{* *}$ & $0.102(0.542)$ & $0.004(0.018)$ \\
\hline CS-differentiation/prospector & $-0.614(-1.639) * *$ & $-0.416(-1.185)$ & $-0.924(-1.631)^{* *}$ & $0.190(0.297)$ \\
\hline CS-cost leadership/defender & $-0.121(-0.537)$ & $-0.353(-1.677)$ & $-0.319(-0.937)$ & $0.372(0.970)$ \\
\hline Marketing concept & $0.422(3.119)^{* * *}$ & $0.417(3.290)^{* * *}$ & $0.472(2.304) * * *$ & $0.206(0.896)$ \\
\hline Customer concept & $0.311(1.975)^{* *}$ & $0.168(1.138)$ & $0.146(0.611)$ & $0.346(1.293)$ \\
\hline Environmental uncertainty & $-0.176(-1.095)$ & $-0.173(-1.148)$ & $0.140(0.578)$ & $0.002(0.008)$ \\
\hline Costing methodology & $0.868(1.724)^{* *}$ & $0.776(1.647)^{* *}$ & $0.743(0.976)$ & $0.863(1.007)$ \\
\hline Company size & $-0.110(-0.651)$ & $0.123(0.779)$ & $0.043(0.167)$ & $-0.036(-0.124)$ \\
\hline Industrial sector & $1.467(2.611)^{* * *}$ & $0.907(1.726)^{* *}$ & $1.597(1.880)^{* *}$ & $1.393(1.458)^{*}$ \\
\hline Adjusted R2 & 0.560 & 0.450 & 0.135 & 0.031 \\
\hline $\mathrm{F}$ & 6.517 & 4.551 & 1.677 & 0.872 \\
\hline $\mathrm{P}$ & $0.0000 * * *$ & $0.001 * * *$ & 0.139 & 0.560 \\
\hline VIF & 1.2642 & 1.2712 & 1.2712 & 1.2642 \\
\hline Tolerance & 0.8004 & 0.8004 & 0.8004 & 0.8004 \\
\hline
\end{tabular}

$\mathrm{CS}=$ competitive strategy. Each cell in the table above presents the regression coefficients, followed by the $\mathrm{t}$-value in brackets. All t-tests are one-tailed tests of significance: $* \mathrm{p}<0.10 \quad * * \mathrm{p}<0.05 \quad * * * \mathrm{p}<0.01$

\subsection{Discussion of the regression results in relation to hypotheses (Table 1)}

\subsubsection{Competitive strategy}

No consistent support is found for $H I a$ and $H 1 b$ concerning a differentiation type CS. The assumption that the use and perceived merit of CA practices is contingent on the employment of a differentiation type strategy is supported by significant positive relationships between CSanalyser and usage of CPAIC and CSPA (both $\mathrm{p}<0.01)$, and perceived merit of CPIAC ( $<<0.01)$ and CSPA $(\mathrm{p}<0.05)$. There is also a significant positive relationship between CSdifferentiation/prospector and usage of $\mathrm{CE}(\mathrm{p}<0.10)$. However, other results oppose the hypotheses, in particular the significant negative relationships between CSdifferentiation/prospector and perceived merit of CPAIC and CLV (both $\mathrm{p}<0.05$ ). Due to these apparent inconsistencies, individual responses were inspected and it was observed that many participants use multiple strategies. It is possible that large firms use different strategies for different products or markets, and some firms may use a hybrid strategy (Thornhill and White, 2007) and thus the relationship between strategy and CA is highly complex.

\subsubsection{Market orientation}

Quite strong support is obtained for $H 2 a$. There are significant positive relationships between the marketing concept and usage of CPAIC $(\mathrm{p}<0.05)$ and CSPA $(\mathrm{p}<0.01)$ and, as might be expected, between the customer concept (which requires tailored offerings to individual customers) and CPAIC usage $(\mathrm{p}<0.10)$. Stronger support is obtained for $H 2 b$, with significant positive relationships between the marketing concept and perceived merit of three CA practices: CSPA, CPAIC and CLV (all $\mathrm{p}<0.01$ ) and a significant positive relationship between the customer concept and perceived merit of CPAIC $(\mathrm{p}<0.05)$. This is consistent with the belief that 
companies which move on from the marketing concept (a focus on customer segments) to the customer concept (a focus on individual customers) would benefit from CPA focused on individual customers (Kotler 2003) and hence the evidence demonstrates that adoption of the customer concept is a likely contingent variable that directly affects the use of CA practices.

\subsubsection{Environmental uncertainty}

Some support is found for $H 3 a$, as a significant positive relationship between an organic structure and usage of CE $(\mathrm{p}<0.05)$ is revealed. However, the lack of significant relationships with any other CA practice may indicate that an environmental uncertainty construct that is more representative of customer-level complexities is needed. Propensity to switch to another supplier is a key customer related uncertainty (Lopez et al., 2006), hence future researchers may consider designing an environmental uncertainty construct that captures customer switching trends, as this may be a better indicator of the need for CA. There is no support for $H 3 b$.

\subsubsection{Costing methodology}

Some support is found for $H 4 a$ and $H 4 b$ concerning $\mathrm{ABC}$ adoption. There are significant positive relationships between $\mathrm{ABC}$ adoption and CPAIC usage $(\mathrm{p}<0.10)$ and the perceived merit of CPAIC and CSPA (both $\mathrm{p}<0.05$ ). However, no significant relationship is found between ABC adoption and other CA practices.

\subsubsection{Company size}

Little support is found for $H 5 a$ and $H 5 b$. The only significant relationship is between company size and use of CSPA $(\mathrm{p}<0.10)$. This is not surprising as a large product focussed company with a cost leadership strategy would not need to measure CA. However, Chenhall (2003) argues that the complexity regarding the presence of a large customer base could be handled by making use of CA practices and therefore number of customers might be a more relevant measure for company size in future studies of this type.

\subsubsection{Industrial Sector}

Some support was found for $H 6 a$, as results show that belonging to the financial services sector is significantly positively related to use of CPAIC ( $\mathrm{p}<0.01$ ). Strong support is found for $H 6 b$, as belonging to the financial services sector is significantly related to the perceived merit of all four CA practices. This indicates that companies in the financial services sector see potential benefits from using CA practices, even if actual usage is not presently high. However, only four of the fourteen quoted companies in the NZ financial service sector responded to this survey and the small sample size may explain why there was only one significant finding in relation to CA usage rates. It is therefore recommended that future researchers consider examining this factor again, perhaps within a survey on a larger population.

\section{Conclusions and future research}

This survey finds mean scores for the usage and perceived merit of CA practices in NZ in 2009 to be similar to those found by Guilding and McManus (2002) in Australia, and significantly higher than those reported in NZ two years previously by Lord et al. (2007). As this survey uses an amended methodology, by excluding the previously misinterpreted holistic measure of CA, it is not clear whether the higher usage rates in NZ do indicate actual increased usage over time, or are due to more accurate survey results, or some combination of these and other factors. 
Moreover, the comparison of usage rates between Australia and NZ is at different times, and since 2002 the usage of CA in Australia may have increased. Hence, future researchers should consider carrying out a comparative study to investigate CA usage rates in Australia and NZ simultaneously.

With respect to CS, this study highlights a plethora of different findings, across the different CA practices, with some supporting and others opposing the assumed contingent relationship between use of a differentiation type strategy and usage and perceived merit of CA practices $(H I a$ and $H 1 b)$. As survey participants were NZX listed companies, they are inevitably large and may be diversified and likely to use different strategies for different products or markets. Moreover, some may use a hybrid strategy (Thornhill and White, 2007). Therefore, the relationship between strategy and CA is highly complex (Langfield-Smith, 1997) and there is much scope for future researchers to examine in detail the contingent relationship between alternative competitive strategies and CA practices. Given the difficulty of accurately identifying company strategy via a survey, case study research may be more appropriate for such investigations.

In line with the Australian study, but in contrast to the prior New Zealand study, this study finds strong support for a contingent relationship between market orientation and the usage and perceived merit of CA practices ( $H 2 a$ and $H 2 b$ ), as the marketing concept is found to have a significant positive relationship with CSPA and CPAIC usage and perceived merit of CSPA, CPAIC and CLV. This is the first study to separately identify the customer concept as a specific type of market orientation and find it to have a significant positive relationship with both usage and perceived merit of CPAIC. This finding is consistent with Kotler's (2003) advice that firms adopting the customer concept, and hence forging one to one relationships with individual customers, should measure CPAIC, and suggests that the customer concept is a specific contingent factor that drives the need for CPAIC, a contention that warrants testing in future research.

Some support is found for a contingent relationship between $\mathrm{ABC}$ adoption and usage and perceived merit of CA practices $(\mathrm{H} 4 a$ and $\mathrm{H} 4 b)$, as CPAIC usage and perceived merit of CPAIC and CSPA were all significantly positively related to ABC usage. The absence of significant relationships with other $\mathrm{CA}$ practices is surprising given that the need for CA measures is often cited as being a key reason for the adoption of $\mathrm{ABC}$ (For example, Innes et al., 2,000). However, this finding may be evidence that companies that have implemented ABC for product profitability measurement still struggle to measure CP (Bates and Whittington, 2009; Hinterhuber, 2008). Alternatively, some of the survey participants who are using CA may not use ABC because they are following the advice of Ward (1992) and using a marginal costing approach to CPA. Such issues could be investigated in future research.

Some support is found for a contingent relationship between industry sector and usage and perceived merit of CA practices $(H 6 a$ and $H 6 b)$. Specifically, the financial services sector is significantly positively related to CPAIC usage and perceived merit of all four CA practices. The evidence is likely to be restricted by a small sample size and hence future researchers are advised to investigate this contingent relationship using surveys on a larger population. 
It had originally been the intention in this research to investigate any differences in attitude towards CA between participants from accounting and marketing disciplines. Hence, the questionnaire was sent to both chief accountants and marketing managers in each company surveyed. Unfortunately, this objective could not be pursued as in no case did the chief accountant and marketing manager both respond. There is evidence that successful CA developments have been associated with the involvement of marketing personnel, whilst accountants have been reluctant to take charge of forward-looking CA measures, claiming a lack of relevant skills (Andon et al., 2001). Moreover, Roslender and Hart (2002) call for greater inter-functional cooperation between MA and marketing with respect to the development of CA practices. It is therefore recommended that future CA research, of a survey or case study nature, should specifically investigate differences in usage of, and attitudes towards, CA practices between the two disciplines.

\section{Notes}

1. The term $C L V$ is prevalent in the recent literature and hence is used throughout this paper. The alternative term Lifetime CPA is used in the two prior surveys. It is believed that these are merely alternative terms for the same type of CA measure. Hence, for this survey both terms are treated as synonymous in the survey instrument and when comparing survey results with the prior surveys.

2. Similarly, the term $C E$ is prevalent in the recent literature and hence is used throughout this paper. The alternative term valuation of customers or customer groups as assets is used in the two prior studies. It is believed that these are merely alternative terms for the same type of CA measure, hence for this study both terms are treated as synonymous in the survey instrument and when comparing results with the prior surveys.

3. In some databases this paper is alternatively cited as Shanahan, Y. P., Lord, B. R. and Nolan, B. M. (2007). The use and perceived merit of customer accounting in New Zealand. Accounting Research Journal, Vol. 20, No. 1, pp. 47-59.

4. This case was subsequently revised and renamed Allied Office Products in Shank (2001) and in both publications is cited as an adaptation of an earlier version of the case by Govindarajan and Weiss first published in 1992.

5. The term customer profitability analysis is used in both prior studies when meaning CPA calculated for individual customers (as opposed to CPA calculated for customer segments). For this study the clearer term customer profitability analysis-individual customers $(C P A I C)$ is used in the survey instrument and throughout the paper.

6. A mean score that is above the midpoint signifies relatively high usage rates as scores are nearer to 'to a large extent' than to 'not at all' on the Likert measurement scale.

7. The prior NZ survey results are distorted because the mean scores for usage and perceived merit of the holistic term CA, which is meant to include all types of CA, are lower than the mean scores for both CPAIC and CSPA.

8. The 9 exclusions were because 4 recipients advised that they would not be able to participate due to time constraints and 5 due to lack of relevance of the study to the company.

9. Reasons stated were: it was company policy not to respond to surveys, the company did not have a relevant customer base, the recipient was not the right person in the company to be surveyed (this latter reason was mentioned mostly by marketing managers).

10. A three month time period for completing an honours thesis.

11. The "N/A" option was included for questions 1 to 4 , CA usage, and perceived managerial merit of CA, competitive strategy and market orientation, to indicate that an approach was not applicable to the organization at all. Participants reporting N/A were coded as " 1 ". The point to be noted here is that, both the "not at all", and the "not applicable" options were coded as " 1 " in the data analyses phase. Re-analysing data by excluding the "N/A" option had minimal effects on the reported results. 


\section{References}

Al-Omiri, M. and Drury, C. (2007), "A survey of factors influencing the choice of product costing systems in UK organisations", Management Accounting Research, Vol. 18 No 4, pp. 399-424.

Andon, P., Baxter, J., and Bradley, G. (2001), "Calculating the economic value of customers to an organisation”, Australian Accounting Review, Vol. 11 No. 1, pp 62-72.

Bates, K. and Whittington, M. (2009), "The Customer Is King. Enthroned or In Exile? An Analysis of the Level of Customer Focus in Leading Management Accounting Textbooks", Accounting Education: an international journal, Vol. 18 No. 3, pp. 291-317.

Bell D., Deighton, J., Reinartz W.J., Rust R.T. and Swartz G. (2002), "Seven Barriers to Customer Equity Management", Journal of Service Research, Vol. 5 No. 1, pp. 77-85.

Bjørnenak, T. and Mitchell, F. (2002), "The development of activity-based costing journal literature, 1987-2000”, European Accounting Review, Vol. 11 No. 3, pp. 481-508.

Blattberg, R.C., and Deighton, J. (1996), "Manage Marketing by the Customer Equity Test", Harvard Business Review, Vol. 74 No. 4, pp. 136-144.

Chapman, C. (1997), "Reflections on a contingent view of accounting", Accounting, Organizations and Society, Vol. 22 No. 2, pp. 189-205.

Chenhall, R. (2003), "Management control system design within its organizational context: Findings from contingency-based research and directions for the future", Accounting, Organizations and Society, Vol. 28 No. 2-3, pp. 127-168.

Chenhall, R. and Chapman, C. (2006), "Theorising and testing fit in contingency research on management control systems", in Hoque Z. (Ed.), Methodological issues in accounting research: Theories, methods and issues, Spiramus, London, pp. 35-54.

Cotton, W.D.J., Jackman, S.M. and Brown, R.A. (2003), "Note on a New Zealand replication of the Innes et al. UK activity-based costing survey", Management Accounting Research, Vol. 14 No. 1, pp. 67-72.

Foster, G. and Gupta, M. (1994), "Marketing, cost management and management accounting”, Journal of Management Accounting Research, Vol. 6 pp. 43-77.

Foster, G., Gupta, M. and Sjoblom, L. (1996), "Customer profitability analysis: Challenges and new directions", Journal of Cost Management, Vol. 10 No. 1, pp. 5-17.

Gleaves, R., Burton, J., Kitshoff, J., Bates, K., and Whittington, M. (2008), “Accounting is from Mars, marketing is from Venus: establishing common ground for the concept of customer profitability", Journal of Marketing Management, Vol. 24 No. 7-8, pp. 825-845.

Guilding, C. and McManus, L. (2002), "The incidence, perceived merit and antecedents of customer accounting: an exploratory note", Accounting, Organizations and Society, Vol. 27 No. 1-2, pp. 45-59.

Hart, A. and Smith, M. (1998), "Customer profitability audit in the Australian banking sector". Managerial Auditing Journal, Vol. 13 No 7, pp. 411-415.

Hinterhuber, A. (2008), "Customer value-based pricing strategies: why companies resist", Journal of business strategy, Vol. 29 No. 4, pp. 41-50.

Innes, J. and Mitchell, F. (1995), “A survey of activity based costing in the UK's largest companies", Management Accounting Research, Vol. 6 No. 2, pp. 137-153. 
Innes, J., Mitchell, F., and Sinclair, D. (2000), “Activity based costing in the UK's largest companies: a comparison of 1994 and 1999 survey results", Management Accounting Research, Vol. 11 No 3, pp. 348362.

Jacobs, F., Johnston, W. and Kotchetova, N. (2001), "Customer Profitability: Prospective vs. Retrospective Approaches in a Business-to-Business Setting”, Industrial Marketing Management, Vol. 30 No. 4, pp. 353-363.

Kaplan, R. S. (1984), “The Evolution of Management Accounting”, Accounting Review, Vol. 59 No. 3, pp. 390-418.

Kaplan, R. S. (1989), Kanthal (A), Harvard Business School Case 190-002. Boston, MA.

Kaplan, R.S. and Cooper, R. (1998), Cost and effect: using integrated cost systems to drive profitability and performance, Harvard Business School Press, Boston, MA.

Kaplan, R. and Narayanan, V.G. (2001), "Measuring and managing customer profitability", Journal of cost management, Vol. 15 No. 5, pp. 5-15.

Kotler, P. (2003), Marketing Management, $11^{\text {th }}$ ed., Pearson Education, Upper Saddle River, New Jersey.

Kotler, P. and Keller, K.L. (2006), Marketing Management, $12^{\text {th }}$ ed., Pearson Education, Upper Saddle River, New Jersey.

Langfield-Smith, K. (1997), "Management control systems and strategy: A critical review. Accounting, Organizations and Society", Vol. 22 No. 2, pp. 207-232.

Lindsay, R. M. (1994) "Publication system biases associated with the statistical testing paradigm", Contemporary Accounting Research, Vol. 11 No. 1, pp. 33-57.

Lindsay, R.M. (1995) "Reconsidering the status of tests of significance: An alternative criterion of adequacy", Accounting, Organizations and Society, Vol. 20 No. 1, pp. 35-53.

Lopez, J.P.M., Redondo, Y.P. and Olivan, F.J.S. (2006), "The impact of customer relationship characteristics on customer switching behaviour", Managing Service Quality, Vol. 16 No. 6, pp. 556-574.

Lord, B.R., Shanahan, Y.P., and Nolan, B.M. (2007), "The use and perceived merit of customer accounting in New Zealand”, Accounting Research Journal, Vol. 20 No. 1 pp. 47-59[3].

McManus, L. and Guilding, C. (2008), "Exploring the potential of customer accounting: a synthesis of the accounting and marketing literatures", Journal of Marketing Management, Vol. 24 No. 7-8, pp. 771-795.

Mitchell, M. (2004), “ABC trends in the banking sector: a practitioner's perspective”, Journal of Performance Measurement, Vol. 17 No. 3, pp. 23-41.

Mulhern, F.J. (1999), "Customer Profitability Analysis: Measurement, Concentration and Research Directions”, Journal of Interactive Marketing, Vol. 13 No. 1, pp. 25-40.

Narver, J.C. and Slater, S.F. (1990), "The effect of market orientation on business profitability", Journal of Marketing, Vol. 54 No. 4, pp. 20-35.

Otley, D.T. (1980), "The contingency theory of management accounting: Achievement and prognosis". Accounting, Organizations and Society, Vol. 5 No. 4, pp. 413-428.

Rafiq, A. and Garg, A. (2002), "Activity based costing and financial institutions: old wine in new bottles or corporate panacea?" The journal of bank cost and management accounting, Vol. 15 No. 2, pp. 12-28.

Roslender, R. and Hart, S. J. (2002), Marketing and management interfaces in the enactment of strategic management accounting practices: An exploratory investigation, CIMA Publications, London. 
Shank, J.K. (1996), Cases in cost management: A strategic emphasis, South-Western College Publishing, Cincinnati, Ohio.

Shank, J.K. (2001), Cases in cost management: A strategic emphasis, South-Western College Publishing, Cincinnati, Ohio.

Shields, M.D. (1997), "Research in Management Accounting by North Americans in the 1990's", Journal of Management Accounting Research, Vol. 9, pp. 33-61.

Smith, M. (2002), "Derrick's Ice-cream company: applying the BCG matrix in customer profitability analysis", Accounting Education, Vol. 11 No. 4, pp. 365-375.

Storbacka, K. (1997), "Segmentation Based on Customer Profitability: Retrospective Analysis of Retail Bank Customer Bases”, Journal of Marketing Management, Vol. 13 No. 5, pp. 479-492.

Storbacka K. (2006), Driving Growth with Customer Asset Management, WSOY, Helsinki.

Thornhill, S., and White, R. E. (2007), "Strategic Purity: A Multi-Industry Evaluation of Pure vs. Hybrid Business Strategies”, Strategic Management Journal, Vol. 28 No. 5, pp. 553-561.

Treacy, M. and Wiersema, F. (1993), "Customer Intimacy and Other Value Disciplines", Harvard Business Review, Vol. 71 No. 1, pp. 84-93.

Ward, K. (1992), Strategic Management Accounting, Butterworth-Heinemann, Oxford.

Weir, K. (2008), "Examining the theoretical influences of customer valuation metrics", Journal of Marketing Management, Vol. 24 No. 7/8, pp. 797-824.

Yin, R. K. (2009), Case study research: Design and methods, 4th ed., Sage Publications, Los Angeles.

\section{Appendix}

Table 8:- Acronyms used

\begin{tabular}{|l|l|}
\hline Abbreviation & Explanation \\
\hline ABC & Activity-based costing \\
\hline ABCM & Activity-based cost management \\
\hline CA & Customer accounting \\
\hline CE & Customer equity \\
\hline CLV & Customer lifetime value \\
\hline CP & Customer profitability \\
\hline CS & Competitive strategy \\
\hline CPA & Customer profitability analysis \\
\hline CPAIC & Customer profitability analysis-individual customers \\
\hline CSPA & Customer segment profitability analysis \\
\hline Lifetime CPA & Lifetime customer profitability analysis \\
\hline MA & Management accounting \\
\hline MCS & Management control systems \\
\hline
\end{tabular}




\section{Glossary of Terms used in the Questionnaire.}

Customer Accounting "includes all accounting practices directed towards appraising profit, sales, or present value of earnings relating to a customer or group of customers" (Guilding and McManus, 2002, p. 48).

Customer Profitability Analysis-Individual Customers (CPAIC), also sometimes called customer account profitability or customer profitability (CP) (Weir, 2008), involves calculating profit earned from a specific customer. The profit calculation is based on costs and sales that can be traced to a particular customer. This technique allows for the identification of the most profitable customers. (Guilding and McManus, 2002).

Customer Segment Profitability Analysis (CSPA) is the practice of measuring CP on a segment or customer group basis rather than on individual customers as for CPAIC.

Lifetime CPA, also known as customer lifetime value (CLV), involves extending the time horizon for CP analysis to include future years. The practice focuses on all anticipated future revenue streams and costs involved in servicing a particular customer or customer group (Guilding and McManus, 2002).

Customer Equity (CE) refers to the valuation of customers or customer groups as assets which involves the calculation of the value of customers for the company (Guilding and McManus, 2002). CE is also commonly described as the sum of individual discounted lifetime values of both present and future customers for the duration of time that they continue to transact with the company (Weir, 2008).

Competitive Strategy relates to each business unit of the organisation and focuses on how individual strategic business units (SBU) compete within their particular industries and the way each SBU positions itself in relation to competitors. (Chapman, 1997).

\section{Types of Competitive Strategy:}

- Cost Leadership: implies that the organisation aims to become the lowest cost provider in its industry. The source of its competitive strategy may arise from factors such as economies of scale, access to favourable raw material prices, and superior technology (Chapman, 1997).

- Differentiation: companies with a differentiation strategy focus on providing products and services with attributes that are highly valued by its customers. These include quality or dependability of product, after-sales service, the wide availability of the product and product flexibility. (Chapman, 1997).

- Defenders: defenders have a narrow product range and undertake little product or market development. The functions critical for organisational success are finance, production and engineering, with less emphasis on marketing and research and development (Chapman, 1997).

- Prospectors: prospectors are described as continually searching for market opportunities and as being the creators of change and uncertainty to which their competitors must respond. The marketing and research and development functions dominate finance and production, so efficiency and profit performance are not as important as maintaining industry leadership in product innovation (Chapman, 1997).

- Analysers: analysers combine the strongest characteristics of defenders and prospectors (Chapman, 1997). 


\section{The Company's Orientation towards the Market Place:}

- Production Orientation: in production-oriented businesses consumers prefer products that are widely available and inexpensive. These businesses concentrate on achieving high production efficiency, low costs and mass distribution (Kotler and Keller, 2006).

- Product Orientation: in product-oriented businesses consumers favour products that offer the most quality, performance or innovative features. Managers in these organisations focus on making superior products and improving them over time (Kotler and Keller, 2006).

- Selling Orientation: selling-oriented businesses hold that consumers, if left alone, would buy enough of the organisation's products. The organisation must therefore, undertake an aggressive selling and promotion effort. The selling oriented concept is practiced most aggressively with unsought goods, which are goods that buyers normally do not think of buying (Kotler and Keller, 2006).

- Market Orientation: a market oriented business starts with a well-defined market, focuses on customer needs, and coordinates all activities that will affect customers and produces profits by satisfying customers. These businesses focus on customer segments rather than on individual customers. The organisational goals of such businesses require them to be more effective than competitors in creating, delivering and communicating superior customer value to their chosen markets (Kotler and Keller, 2006).

- Customer Orientation: Customer-oriented businesses follow the same philosophy adopted by marketoriented businesses. However, the main difference between customer-oriented and market-oriented businesses is that customer-oriented businesses focus on individual customers rather than on customer segments (Kotler, 2003).

Organisational Structure: Organisations normally lie on the continuum between 'mechanistic' and 'organic'.

- Mechanistic: the mechanistic organisation is seen as a suitable response to a stable environment. Its activities are broken down into specialized parts which are integrated by means of a vertical hierarchy. If activities can be planned in advanced, and need not be adjusted unduly as events unfold, then the vertical hierarchical structure represents a highly efficient framework for allowing the co-ordination of necessary activity (Chapman, 1997).

- Organic: this structure arises in response to an unstable environment. In an unstable setting, a "mechanistic" response, as described above, is inappropriate. In these organisations, pre-planning is virtually impossible and individuals have to carry out their job with the knowledge of overall purpose and the situation of the company as a whole. In this setting, different sub-units are required to mutually adjust their operations in order to achieve the overall goal of the organisation (Chapman, 1997).

Activity-Based-Costing ( $A B C)$ : an $A B C$ system overcomes the distorted product cost inherent in traditional volume based cost systems by focussing on activities rather than products and by using many secondary stage bases to allocate costs to products. Some of these bases are used to trace inputs that vary directly with the number of items produced, while others are used to trace inputs whose consumption does not vary with quantity (Kaplan, 1984).

Turnover: annual sales volume net of all discounts and sales taxes 